\title{
INFODEMIC AS SOCIAL CHALLENGE: INTERNATIONAL, REGIONAL, NATIONAL SETTINGS
}

\author{
Olga Gorbatenko \\ Associate Prof., PhD, RUDN University, Law Institute Department of Foreign Languages, \\ RUSSIAN FEDERATION, \\ olgagorbatenko@inbox.ru
}

\begin{abstract}
The paper focuses on of the most critical social challenges during the current pandemic. It aims to consider the phenomenon of infodemic at international, regional, and national levels.

The paper provides concrete examples of the mentioned trends and features.

The research materials include the UNO, World Health Organization, EU documents, and national documents of several countries, mass media statements with regard to the infodemic roots, essence, tools, actors, consequences.

The research methodology rests on the comparative qualitative approach to the data analysis, also uses the case study techniques as each research item is considered as a case. Totally over 250 items were subject to study.

The results show that the international community realizes the threat of infodemic, recognizes the need of coordinated response in the form of communication policies.

As far as the national level is concerned, many countries take legislation measures to combat the infodemic, introduced amendments to the administrative and criminal legal acts to impose administrative and criminal liability of physical and legal persons whose disinformation activities cause harm to other people lives and health.

The findings lead to the conclusion on the need to the coordinated policy of the information provision within emergency settings at international, regional, and local national levels. The paper also considers some examples of such an approach within national practices of several countries and as an additional information sets forth brief outline of national universities activities that helped to play down and counter the disinformation at microlevel, with regard to information provision within a particular region of the country.
\end{abstract}

Keywords: COVID 19, Infodemic, social challenges, legislation response.

\section{INTRODUCTION}

The world faces unprecedent threat and challenge to its civilization due to COVID 19 spread.

The pandemic has caused enormous troubles in terms of human lives, health and survival, economic, social, and political stability in the countries. Moreover, the phenomenon of disinformation has also spread globally and affected societal stability and human psychological conditions as it disseminated panic and fear among people.

The present paper aims to consider international, regional and national social reactions and legal actions and visions with regard to the phenomenon of infodemic.

Amid the unprecedent spread of COVID 19, the international community has recognized that infodemic has 
become a part of the pandemic emergency, a kind of social challenge that peoples face across the world.

The international and regional organizations, national and local authorities have been combating the phenomenon while solving other medical, social, economic tasks to overcome the COVID 19 challenges. The infodemic hurts human lives, affects families and communities, seeds panic and the feeling of fear and uncertainty (El-Gilany, 2020, Sabat et al., 2020).

Therefore, international community takes coordinated measure to stop it (Gallotti et al., 2020), recognizes the negative role of digital media (Bechmann, 2020), and call for the information hygiene to mitigate conspiracy theory and infodemic impact on people (Grimes, 2020).

Scholars also underline that the adequate communication during the pandemic health emergencies is a crucial tool to provide sustainability in society (Atabekova, 2020, Patel et al., 2020).

Earlier studies confirm that discourse studies are socially important to implement the language use policy that can protect humans rom harmful communication (Atabekova, 2019a,b; Atabekova et al., 2019; Bayer, 2020; Piiparinen, 2020).

Bearing in mind the above context, the present paper aims to consider relevant administrative -legislative documents that aim to combat the phenomenon of infodemic in contemporary global society.

\section{MATERIALS AND METHODS}

The research materials include the UNO, World Health Organization, EU documents, and national documents of several countries, mass media statements with regard to the infodemic roots, essence, tools, actors, consequences.

The research methodology rests on the comparative qualitative approach to the data analysis, also uses the case study techniques as each research item is considered as a case. Totally over 250 items were subject to study.

\section{RESULTS AND DISCUSSSION}

In April 2020 the UN Secretary- General launched a special initiative under the title United Nations Communications Response (5 ways...2020). It aims to fight the dissemination mis- and disinformation. Further on May 11, 2020 the UN also issued a Guidance Note on Addressing and Countering COVID-19 related Hate Speech (UN Guidance Note, 2020). The documents address various stakeholders, including UN agencies, Member States, social media and tech companies, media, civil society and other stakeholders and call for balance between the protection of fundamental rights for freedom of information, opinion and expression, on the one hand, and protection of human lives and dignity, on the other one.

The World health Organizations states that the infodemic is an overabundance of information, as well as deliberate attempts to spread false information. Infodemic can harm the physical and mental health of people, lead to poor adherence to public health measures, and people who refuse testing and immunization (Managing the COVID-19 infodemic...2020).

At the World Health Assembly in May 2020, WHO Member States passed Resolution WHA73.1 on the COVID-19 response. The Resolution recognizes that managing the infodemic is a critical part of controlling the COVID-19 pandemic.

The World Health Organization underlined the importance of "providing the population with reliable and comprehensive information on COVID-19" and urged the national authorities to take measures to counter misinformation and disinformation and as well as malicious cyber activities". The statement was part of the Official Statement adopted at the 73rd World health Organization assembly (COVID 19 Response, 2020).

The EU has officially distinguished the difference between misinformation and disinformation that both refer to the false information and differ in term of unintentional (misinfromation) or intentional ( disinformation) spread with the aim to cause harm ( Fighting disinformation, 2020).

The Council of the EU has adopted special conclusions which state that the increased spread of disinformation poses a kind of hybrid threats to the EU member states.

The conclusions call for proactive approach to address the disinformation, underline the need for preventive measures, tools to detect, qualify and identify sources thereof.

The conclusions stressed the importance of Strategic Communication Division Task Forces and the Rapid Alert System development to launch a comprehensive platform for Member States and EU Institutions which 
could provide safe and resilient information on the COVID 19 and reinforce the collaboration among agencies within the European institutions and bodies (Council conclusions, 2020).

As for national level, Roxana Radu mentions that national governments across the continents introduce counter measure to stops the spread of fake news about the COVID 19 and criminalize false data dissemination (Radu , 2020).

Thus, South Africa has passed new regulations that criminalize disinformation about the COVID-19 pandemic. Lawyers and politicians say such regulations could potentially prompt other countries to adopt more repressive rules and censorship against the press.

These steps are considered the government's response to the fake news spread within the current pandemic. The regulations were published in the Government Gazette with reference to the 2002 Disaster Management Act. The new regulations lay grounds for various penalties including fines, imprisonment, or both (AfricaNews 2020).

Bolivia has enacted the decree criminalizing "disinformation" on COVID-19 outbreak (Committee to Protect Journalists, 2020).

In the Russian Federation amendments were made to the administrative and criminal legislation concerning the establishment of liability for the dissemination of inaccurate information. By the way, administrative liability for individuals for spreading fakes has been established since March 2019 (part 9-h 10 of article 13.15 of the Administrative Code), but for legal entities it was introduced in 2020 (part 10.1 - h. 10.2 of article 13.15 of the Russian Federation Administrative Code).

In addition, since April 1,2020, criminal liability has also been established for public dissemination of knowingly false information, including those that entailed grave consequences (Articles 207.1-207.2 of the Criminal Code).

Thus, under the Criminal Code of the Russian Federation, Article 207.1. focuses on the Public dissemination of knowingly false information about circumstances posing a threat to the life and safety of citizens (introduced by Federal Law dated 01.04.2020 N 100-FZ) and states the following:

Public dissemination under the guise of reliable messages of deliberately false information about circumstances that pose a threat to the life and safety of citizens, and (or) on measures taken to ensure the safety of the population and territories, methods and methods of protection from these circumstances shall be punishable by a fine in the amount of three hundred thousand to seven hundred thousand rubles, or in the amount of the wage or salary, or any other income of the convicted person for a period from one year to eighteen months, or by compulsory works for a term of up to three hundred and sixty hours, or corrective labor for a term of up to one year, or restriction freedom for up to three years.

It should be noted, that in this article, circumstances posing a threat to the life and safety of citizens are recognized as natural and man-made emergencies, environmental emergencies, including epidemics, epizootics and other circumstances resulting from accidents, dangerous natural phenomena, disasters, natural and other disasters, entailed (which may entail) human casualties, damage to human health and the environment, significant material losses and disruption of the living conditions of the population.

\section{CONCLUDING REMARKS}

The research findings reveal a number of critical points. Among them the following key issues can be mentioned.

First, unprecedent scale of disinformation took place with the involvement of technology and social media. These technologies and social networks led to the emergence of infodemic due to rumors and questionable information.

Second, the data confirms that internet users tend to receive information that matches their worldview and perceptions.

Third, infodemic as affiliated with the pandemic, has emerged as a societal response to increasing uncertainty and complexity.

Forth, much depends on the degree of structural and timely response from the national authorities.

Next, the spread of infodemic is negatively fostered by facts of cultural bias that appear in the mass media headlines and political statements. 
The findings lead to the conclusion on the need to the coordinated policy of the information provision within emergency settings at international, regional, and local national levels.

Further, it should be noted that with regard to the current pandemic and infodemic as its part, cross-sectoral efforts are necessary to investigate the public discourse during such health emergencies, with the view to detect dangerous tendencies in language use, to manage the reliable information provision.

\section{REFERENCE LIST}

5 ways the UN is fighting 'infodemic' of misinformation (2020). UN. https://www.un.org/en/un-coronaviruscommunications-team/five-ways-united-nations-fighting-\%E2\%80\%98infodemic\%E2\%80\%99misinformation

AfricaNews (2020). South Africa enacts regulations criminalizing disinformation on coronavirus outbreak. https://www.africanews.com/2020/03/20/south-africa-enacts-regulations-criminalizing-disinformationon-coronavirus-outbreak

Article 207.1. of the Russian Criminal Code (2020) Public dissemination of knowingly false information about circumstances posing a threat to the life and safety of citizens (introduced by Federal Law dated 01.04.2020 N 100-FZ).

http://www.consultant.ru/document/cons_doc_LAW_10699/9d8a5b6501a01da934c1bbd0ca9b1fd46df 76a72/

Atabekova, A. (2019a).Discourse Studies to Protect Minors against Violence in Sports Towards Discourse Studies Novelty. 6th International Conference on Education and Social Sciences (INTCESS-2019), Dubai, United Arab Emirates, February 04-06, 1185-1189.

Atabekova, A. (2019b).Do Discourse Studies Matter with Regard to Protect Minors against Violence in Sport? 6th International Conference on Education and Social Sciences (INTCESS-2019), Dubai, U ARAB EMIRATES, February 04-06, 1190-1194.

Atabekova, A. (2020). University discourse to foster youth's sustainability in society amidst COVID19: International and Russian Features. Sustainability, 12(18), 7336.

Atabekova, A., Belenkova, N., Gorbatenko, R. (2019). Discourse as a tool to counter extremism: shaping methodology for research.AD ALTA-Journal of interdisciplinary research, 9(1), Special issue 6, 64-68.

Bayer, J. (2020). Double harm to voters: Data-driven micro-targeting and democratic public discourse. Internet Policy Review, 9(1), 1-17.

Bechmann, A. (2020). Tackling Disinformation and Infodemics Demands Media Policy Changes. Digital Journalism, 1-9.

Committee to Protect Journalists (2020). Bolivia enacts decree criminalizing "disinformation" on COVID-19 outbreak. https://cpj.org/2020/04/bolivia-enacts-decree-criminalizing-disinformation.php

Council conclusions (2020, December 15) Council conclusions on strengthening resilience and countering hybrid threats, including disinformation in the context of the COVID-19 pandemic, 15 December 2020. https://www.consilium.europa.eu/en/press/press-releases/2020/12/15/council-calls-for-strengtheningresilience-and-countering-hybrid-threats-including-disinformation-in-the-context-of-the-covid-19pandemic/

COVID 19 Response (2020). Seventy-third WHO Assembly, Agenda item 3. https://apps.who.int/gb/ebwha/pdf_files/WHA73/A73_CONF1Rev1-en.pdf

El-Gilany, A. H.(2020). Infodemics of COVID-19 pandemic. Türkiye Halk Sağlığı Dergisi, 18(Special issue), 86-95.

EU Fighting disinformation (2020). COVID-19 coronavirus pandemic: the EU's response. https://www.consilium.europa.eu/en/policies/coronavirus/fighting-disinformation/\#

Gallotti, R., Valle, F., Castaldo, N., Sacco, P., De Domenico, M. (2020). Assessing the risks of" infodemics" in response to COVID-19 epidemics. arXiv preprint arXiv:2004.03997. 
Grimes, D. R. (2020). Health disinformation \& social media: The crucial role of information hygiene in mitigating conspiracy theory and infodemics. EMBO reports, $21(11)$, e51819.

Managing the COVID-19 infodemic: Promoting healthy behaviours and mitigating the harm from misinformation and disinformation (2020). https://www.who.int/news-room/detail/23-09-2020managing-the-covid-19-infodemic-promoting-healthy-behaviours-and-mitigating-the-harm-frommisinformation-and-disinformation

Patel, M. P., Kute, V. B., Agarwal, S. K., behalf of COVID, O. (2020). "Infodemic" COVID 19: More Pandemic than the Virus. Indian Journal of Nephrology, 30(3), 188.

Piiparinen, T. (2020). Communication, reflexivity and harm principle: what might an ideal speech situation look like in responsibility to protect? Journal of Global Ethics, 16(1), 26-44.

Radu, R. (2020). Fighting the 'Infodemic': Legal Responses to COVID-19 Disinformation. Social Media+ Society, 6(3), 2056305120948190.

Sabat, I., Varghese, N. E., Neuman-Böhme, S., Barros, P. P., Brouwer, W., van Exel, J., ... Stargardt, T. (2020). Battling the infodemics: health communication effectiveness during COVID-19. European Journal of Public Health, 30(Supplement_5), ckaa166-072.

UN Guidance Note (2020). UN Guidance Note on Addressing and Countering COVID-19 related to Hate Speech. https://www.un.org/en/genocideprevention/documents/Guidance\%20on\%20COVID19\%20related\%20Hate\%20Speech.pdf 